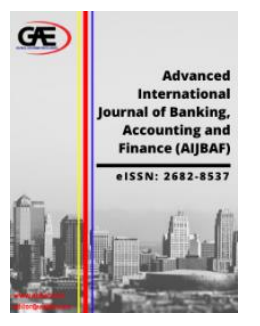

\author{
ADVANCED INTERNATIONAL JOURNAL OF \\ BANKING, ACCOUNTING AND FINANCE \\ (AIJBAF) \\ www.aijbaf.com
}

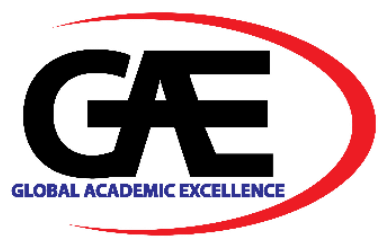

\title{
PREDICTING FINANCIAL DISTRESS IN THE MALAYSIAN MARKET: HAZARD MODEL VERSUS THE LOGIT MODEL
}

\author{
Ahmad Harith Ashrofie Hanafi ${ }^{1 *}$, Rohani Md-Rus ${ }^{2}$, Kamarun Nisham Taufil Mohd ${ }^{3}$ \\ 1 Faculty of Business and Finance,Universiti Tunku Abdul Rahman (UTAR), Malaysia \\ School of Economic, Finance, and Banking, Universiti Utara Malaysia (UUM), Malaysia \\ Email: harith@utar.edu.my \\ 2 School of Economics, Finance, and Banking, Universiti Utara Malaysia (UUM), Malaysia \\ Email: rohani@uum.edu.my \\ 3 School of Economics, Finance, and Banking, Universiti Utara Malaysia (UUM), Malaysia \\ Email: kamarun@uum.edu.my \\ * Corresponding Author
}

\section{Article Info:}

\section{Article history:}

Received date: 06.04.2021

Revised date: 15.04.2021

Accepted date: 28.04.2021

Published date: 15.06.2021

\section{To cite this document:}

Hanafi, A. H. A., Md-Rus, R., \& Mohd, K. N. T. (2021). Predicting Financial Distress In The Malaysian Market: Hazard Model Versus The Logit Model. Advanced International Journal of Banking, Accounting, and Finance, 3 (7), 01-19.

DOI: 10.35631/AIJBAF.37001.

This work is licensed under $\underline{\mathrm{CC} B Y}$ 4.0

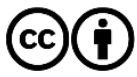

\begin{abstract}
:
The increasing numbers of financially distressed firms in the Malaysian market demonstrate the importance of predicting financial distress among firms in Malaysia. Using firm financial ratios, this study focuses on predicting financial distress using the hazard model and logistic regression (logit model) based on the Malaysian market. This study used listed firms on the Malaysian stock market from 2000 to 2018 to create two sets of data comprising the main sample and holdout sample in order to compare the predictability between hazard and logit models. The results clearly show that the hazard model is better compared to the logit model in predicting financial distress for the Malaysian market since more variables were found to be significant in addition to the model being more consistent in terms of accuracy.
\end{abstract}

Keywords:

Predicting; Financial Distress; Hazard Model; Logit Model 


\section{Introduction}

According to Bursa Malaysia record in 2018, there has been an increase in the number of firms falling under the Practice Note 17 (PN17) status. The number increased from 21 firms in 2017 to 24 firms in the middle of 2018. Although these numbers are relatively small compared to the total number of firms in the market, stakeholders' position and firms' bankruptcy risk level may be affected if this increasing trend continues. Thus, a better understanding of financial distress and bankruptcy risk is imperative.

The term "bankrupt" is defined as the inability to repay debt or also known as insolvency (Sathye, Bartle, Vincent, \& Boffey, 2003). Since debt is an obligation, bankruptcy risk could be defined as the probability that a firm is unable to meet its obligations. Thus, financial distress shows the likelihood of the firm to become insolvent due to the inability to serve its debt obligations. Sathye et al. (2003) explained that debt obligations include the loan principal, interest charge, and other accrued payments. Hence, a firm is in financial distress if it cannot meet its current obligations, where the firm's value is less than the value of its liabilities.

Many methods have been developed to measure the financial distress risk of firms, the most popular of which are Multiple Discriminant Analysis (MDA), Logistic Regression (logit), Probit, Artificial Neural Network (ANN), and Hazard model. Many previous studies used MDA and the logit model (e.g., Altman, 1968; Daily \& Dalton, 1994; Ming \& Akhtar, 2014; Sori, Hamid, Nassir, \& Mohamad, 2001). Altman (1968) introduced the Z-score, which was developed using MDA, and this model has been used by many researchers like Blum (1974) and Wilson and Sharda (1994) to develop a financial distress prediction model. Meanwhile, some other researchers including Ming and Akhtar (2014), Noor, Iskandar, and Omar (2012), and Pindado, Rodrigues, and de la Torre (2008) used the logit model to develop a financial distress model as introduced by Ohlson (1980), who developed the O-score to predict financial distress.

However, some research works have highlighted several problems with both MDA and the logit model. MDA was found to violate the assumption of normality and group dispersion, which may cause bias to the test of significance and estimated error rates (Ohlson, 1980). Ohlson (1980) then attempted to overcome this problem by introducing the logit model, which does not have the same assumption as MDA. This model, which customarily uses average data and is considered as a single-period model, helps in generating the probability of financial distress or financial distress. However, Shumway (2001) and Hillegeist, Keating, Cram, and Lundstedt (2004) argued that the logit model has two econometric problems, which are (1) sample selection bias and (2) the model fails to include the time-varying factor to reflect the risk of financial distress. Hence, the results obtained from the logit model are biased, inefficient, and inconsistent. Shumway (2001) then attempted to overcome the problems encountered by the logit model by introducing the hazard model for the prediction of financial distress. Using the hazard model, Beaver, McNichols, and Rhie (2005), Md-Rus and Abdullah (2005), and Nam, Kim, Park, and Lee (2008) obtained similar results that supported the earlier study by Shumway.

Hence, if the problems that are inherent in MDA and logit in predicting financial distress are considered as serious problems, then the accuracy of the models developed based on both models is questionable. Although the hazard model seems to provide solutions to the econometric problems faced by previous models, its accuracy may not be the best among all Copyright $\odot$ GLOBAL ACADEMIC EXCELLENCE (M) SDN BHD - All rights reserved 
Volume 3 Issue 7 (June 2021) PP. 01-19

DOI 10.35631/AIJBAF.37001

the models. Thus, a study on financial distress prediction models needs to be explored to generate the best model for predicting financial distress that fulfils all econometric assumptions and is able to generate results with high accuracy.

Based on the above, this study used financial ratios to develop financial distress prediction models and to compare the reliability between logit and hazard models in predicting financial distress based on the Malaysian market, because both models generate probabilities that could be compared easily. However, this study did not include the MDA model in the comparison because Lo (1986), which compared the predictability of MDA and logit models, highlighted that the comparison must meet one condition which is the data should satisfy the normal distribution assumption or otherwise, the generated results would be inaccurate. This study used the Malaysian market as its population since most of the previous studies focused on developed markets instead of an emerging market like Malaysia. This study tried to avoid using any prediction models developed by previous studies for developed or other countries since Md-Zeni and Ameer (2010) stated that those models might not be suitable for developing countries due to differences in political and market regulations under which firms operate.

Although some previous studies had developed prediction models based on the Malaysian market, only a few studies made comparisons between the models (Abdullah, Halim, Ahmad, \& Md-rus, 2008; Abdullah \& Halim, 2005; Noor et al., 2012). However, to the best of the author's knowledge, this study is among a few that compared the reliability between hazard and logit models based on the Malaysian market and the first study to compare both models using data from all firms listed on Malaysia stock exchange between 2000 and 2018. Most of the previous studies focused on only a few industries or used a pairing approach between financially distressed and non-financially distressed firms based on a certain criterion, resulting in small sample sizes. In contrast, this study used all the listed firms in Malaysia during the studied period, resulting in a large sample size. Thus, the outcomes of this study are expected to be beneficial for financial institutions, policymakers, and investors. This study highlights the importance of developing accurate financial distress prediction models based on the Malaysian market as these models might affect credit decisions, credit policies, and investment decisions.

\section{Literature Review}

\section{Financial Distress Prediction Models}

Many models have been developed by researchers involving the use of machine learning techniques and statistical techniques to predict financial distress. Beaver (1966) and Altman (1968) are pioneers of the models for financial distress prediction. Altman (1968) employed multiple discriminant analysis (MDA) using financial ratios to predict financial distress for 33 failed and 33 non-failed firms. The results showed that the ratios used were highly significant in predicting financial distress. Based on the results of that study, Altman proposed the Z-score model to predict financial distress by using ratios such as profitability, liquidity, solvency, and cash flow. Thus, it was found that the combination of prediction models and financial ratios could predict firms' potential failure before the failure occurred.

However, Ohlson (1980) highlighted some inherent issues with MDA. MDA was found to violate the assumption of normality and group dispersion, which may result in bias in the test of significance and estimated error rates. This is the main reason why the researchers after Copyright $\odot$ GLOBAL ACADEMIC EXCELLENCE (M) SDN BHD - All rights reserved 
Volume 3 Issue 7 (June 2021) PP. 01-19

DOI 10.35631/AIJBAF.37001

Altman started using other models and shifted their attention away from MDA. Due to these issues, Ohlson (1980) introduced the logit model, which does not have the same assumption as MDA. The logit model was found to be suitable to be used for predicting firms' failure. However, a comparison between MDA and logit models by Lo (1986) showed that the MDA model had higher predictability power compared to the logit model. Nevertheless, this result was based on the condition that the MDA model's data satisfied the normal distribution assumption. According to Shumway (2001) and Hillegeist et al. (2004), the logit model has econometric problems, which could lead to the result become biased, inefficient, and inconsistent.

Due to the weaknesses of the logit model, Shumway (2001) used the hazard model to predict financial distress. Shumway (2001) found that three market and two accounting ratios produced the best result in predicting financial distress. Using a similar sample as Shumway (2001) but covering the period of 1962 to 2002, Beaver et al. (2005) found a similar result that supported the earlier study by Shumway.

In Malaysia, several studies have been conducted to compare the models that predict financial distress for Malaysian firms. In a study that compared MDA with hazard and logit models, Abdullah, Halim, Ahmad, and Md-rus, (2008) found hazard model has higher overall accuracy rate in the estimation model compared to MDA and logit. However, MDA gives a higher accuracy rate when the estimated equation is applied in the holdout sample. This could be caused by the stepwise rather than enter approach adopted in the hazard model.

\section{Determinants of Financial Distress}

Nyamboga, Omwario, Muriuki, and Gongera (2014) asserted that liquidity is one of the indicators of the ability of a firm to meet its short-term obligations. Thus, the firm will try to focus on avoiding a low liquidity position because a lack of liquidity will lead to poor creditworthiness, loss of confidence among creditors, or may lead to the closure of the firm. Researchers including Abdullah (2006), Daily and Dalton (1994), Elloumi and Gueyié (2001), Ganesalingam and Kumar (2001), and Youn and Gu (2010) used the current ratio (CR) in developing their financial distress prediction models. CR can be defined as current assets divided by current liabilities (Elloumi \& Gueyié, 2001; Foster \& Zurada, 2013; Parker, Peters, $\&$ Turetsky, 2002; Wang \& Li, 2007). This ratio directly measures the ability of a firm to meet its short-term obligations using only current assets. Syahida and Ameer (2011) used CR as one of the predictors in predicting the turnover of financially distressed firms in Malaysia. Their result demonstrates the significance of liquidity, represented by CR, in predicting the turnover of financially distressed firms. Thus, it is evident that liquidity is important in predicting the survival of a firm. Meanwhile, Altman, Haldeman, and Narayanan (1977) suggested using the ratio of working capital to total assets because this ratio was found to be able to capture the effect of the liquidity factor in predicting financial distress.

Following the advice by Altman et al. (1977) against using CR to represent liquidity, Ugurlu and Aksoy (2006) used sales to working capital (SWC). They discovered a positive relationship between SWC and the probability of the firm going bankrupt. However, their result contradicted the finding by Yap, Munuswamy, and Mohamed (2012), which used SWC in their study and found it to be insignificant in predicting financial distress. 
Volume 3 Issue 7 (June 2021) PP. 01-19

DOI 10.35631/AIJBAF.37001

In the most recent study by Bakhri, Listyaningsih, and Nurbaiti (2018) that study on Indonesia and used current ratio, quick ratio, and cash ratio to represent liquidity ratio in predicting financial distress. The result obtained shows all ratios were significant to predict financial distress. Meanwhile Darmawan and Supriyanto (2018) used working capital turnover to represent liquidity ratio in predicting financial distress among mining firms in Indonesia market to predict financial distress and found this ratio is significant to predict financial distress. This is similar to study by Pham Vo Ninh, Do Thanh, and Vo Hong (2018) that also found working capital turnover is significant to predict financial distress in Vietnam market.

Using Malaysia market, Jaafar, Muhamat, Alwi, Karim, and Rahman (2018) used quick ratio to represent firm liquidity. However, the result contradicted to Bakhri et al. (2018) since the result obtained shows quick ratio is not has significant impact on financial distress. Waqas and Md-Rus (2018) found that current assets to total liabilities, working capital to total assets, and current assets to current liabilities ratios are significant in predicting financial distress in Pakistan market. Vo, Pham, Ho, and McAleer (2019) that try to predict financial distress based on global financial crisis periods. They found that liquidity ratio consistently significant to predict financial distress after the global financial crisis but insignificant during financial crisis period.

In the later study by Ogachi, Ndege, Gaturu, and Zoltan (2020), current ratio, quick ratio, working capital ratio was included into the financial distress prediction model. The result obtained show only current ratio and working capital ratio that found to be significant to predict financial distress. Fitri and Syamwil (2020) study shows current ratio is insignificant to predict financial distress. The study explained that the insignificant current ratio to predict financial distress could be due to the insignificant different in current ratio value among firms within the study sample. Rafatnia, Ramakrishnan, Abdullah, Nodeh, and Farajnezhad (2020) used working capital to total assets to represent liquidity factor in predicting financial distress using logit model. The results show liquidity found to significant to predict financial distress which also similar to Waqas and Md-Rus (2018)and show the importance of liquidity ratios in predicting financial distress.

Researchers have also used activity ratios in predicting financial distress (e.g., Abdul et al., 2015; Tan \& Dihardjo, 2001; Tirapat \& Nittayagasetwat, 1999; Wang \& Li, 2007). Activity ratios or efficiency ratios, as highlighted by Youn and $\mathrm{Gu}(2010)$, are useful in evaluating the productivity of firms based on the available assets.

Ong, Yap, and Khong (2011) used days sales in receivable under the activity ratio as a predictor in the prediction model for the Malaysian market and found it to be significant in predicting firms' failure. This is because the ratio reflects the ability of a firm to collect payments from their credit sales. Ong, Yap, and Khong (2011) explained that the faster the firm is able to collect from their credit sales, the faster the money collected could be used to settle the firm's debts, which would help to reduce the probability of the firm becoming a financially distressed firm.

In more recent study, Ogachi et al. (2020) used inventory turnover, asset turnover, and debtors turnover to represent activity ratios in their prediction model. The result obtained show all activity ratios were significant in predicting financial distress. This is similar to Fitri and Syamwil (2020) that also used total asset turnover to represent activity ratios and found this Copyright (C) GLOBAL ACADEMIC EXCELLENCE (M) SDN BHD - All rights reserved 
Volume 3 Issue 7 (June 2021) PP. 01-19

DOI 10.35631/AIJBAF.37001

ratio is significant to predict financial distress. The study explained that if firm able to manage and generate sales from the asset, it could help to reduce firm's financial distress.

Profitability indicates the ability of a firm to generate profits and is commonly represented by the profitability ratios (Nyamboga et al., 2014). Various profitability ratios have been used by researchers in predicting firms' financial distress, and one of them is earnings before interest and tax to sales or EBITS (Abdul Manab et al., 2015; Parker et al., 2002; Tan \& Dihardjo, 2001; Thai, Goh, Teh, Wong, \& Ong, 2014; Ugurlu \& Aksoy, 2006). Parker et al. (2002) used this ratio as a proxy to return on assets, which also represents the ability of a firm to recover from financial distress. Parker et al. (2002) believe that this ratio should have a negative relationship with the probability of financial distress.

Some researchers used simple ratios such as net profit margin or NPM (Pindado et al., 2008; Z. Wang \& Li, 2007). Yap et al. (2012) found NPM to have a significant negative effect in predicting firms' financial failure. However, researchers such as Youn and Gu (2010) argued that using profitability ratios in predicting financial distress is similar to predicting profitability using a profitability ratio and this approach will affect the accuracy of the prediction model. This argument is only suitable if financial distress is defined as the inability of the firm to generate profits. Thus, Syahida and Ameer (2011) stressed on the importance of the profitability ratios in predicting financial distress or turnover, as profitability ratios were found to be statistically significant in distinguishing firms according to certain criteria such as bankrupt firms and surviving firms.

Bakhri et al. (2018) used return on assets, net profit margin, return on equity, gross profit margin, and return on sales to represent profitability ratio as predictors in the financial distress prediction model. The study found all ratios were significant to predict financial distress. The result supported by recent study of Fitri and Syamwil (2020) that also used return on equity to represent profitability in predicting financial distress for manufacturing firms in Indonesia. Darmawan and Supriyanto (2018) used retained earnings to total assets and earnings before interest and taxes to total assets to measure the ability of profitability ratios in predicting financial distress. The result obtained similar to Bakhri et al. (2018) and Pham Vo Ninh et al., (2018).

Pham Vo Ninh et al., (2018) highlight the importance accounting variables including both ratios in predicting financial distress as it help to increase the model's accuracy and make the model become more comprehensive. Jaafar et al. (2018) used return on assets as one of the variables in examine the determinants of financial distress in Malaysia market and found to has significant impact on financial distress. Waqas and Md-Rus (2018) that focus on Pakistan market found that that net income to total assets, retained earnings to total assets, and earnings before interest and tax to total assets are significant to predict financial distress using logit model and suggested that profitability ratios are important profitability ratios in predicting financial distress. Vo et al. (2019) found a mixed result for profitability ratios for Vietnam market. This is because the results show during global financial crisis period only earnings before interest and taxes to total assets that found to be significant in predicting financial distress but both ratios found to significant to predict financial distress during post global financial crisis period. 
Volume 3 Issue 7 (June 2021) PP. 01-19

DOI 10.35631/AIJBAF.37001

Ogachi et al. (2020) used firm listed in Nairobi stock market to predict financial distress. This study also include return on assets and return on equity into the prediction model to represent profitability ratios. However, the result obtained show both ratios were dropped from the estimated model which indicate both ratios do not have significant impact in predicting financial distress. This results contradicted to Bakhri et al. (2018). Rafatnia et al. (2020) used earnings before interest and tax to total assets ratio to represent profitability ratios in predicting financial distress. The result obtained shows that this ratio is significant to predict financial distress which similar to result obtained by Waqas and Md-Rus (2018).

Leverage plays an essential role in determining a firm's financial position. For long-term creditors, a firm's long-term debt position is crucial since it affects the firm's capital structure (Nyamboga et al., 2014). One of the many leverage ratios is the debt ratio. Lee and Yeh (2004) and Parker et al. (2002) defined the debt ratio as the total debt divided by the total assets. Beaver (1966) and Ohlson (1980) found this ratio to be significant in predicting financial distress. Instead of using the debt ratio, Ugurlu and Aksoy (2006) used the ratio of long-term debt to total debt since it indicates the reliance of the firm on long-term debt as a source of finance. Ugurlu and Aksoy (2006) found that an increase in a firm's long-term debt to total debt ratio significantly decreased the firm's probability of facing financial failure or financial distress. Halim and Aihmad (2005) used shareholders' funds to total liabilities to represent the leverage ratio because this ratio stands for the capital structure of the firm. They found this ratio to be a significant predictor of financial distress. Thus, a firm that relies too much on liabilities would have a high probability of getting into a financial distress situation. Meanwhile, Chen et al. (2013), Fich and Slezak (2008), and Youn and Gu (2010) included financial cost elements as their variables, such as the interest coverage ratio (ICR). This ratio contains wide-ranging information related to earnings, productivity, ability to pay interest, and indebtedness of the firm (Youn \& $\mathrm{Gu}, 2010$ ). Youn and $\mathrm{Gu}$ (2010) used the logit model and they discovered a negative coefficient for the interest coverage ratio, indicating that a firm with a high-interest coverage ratio would have a low probability of encountering financial distress.

In predicting financial distress based on mining firms in Indonesia, Darmawan and Supriyanto (2018) used book value of equity to total liabilities as a proxy for leverage ratios. The result obtained shows this ratio significant to predict financial distress that indicate leverage is one of the important predictor in predicting financial distress. Jaafar et al. (2018) used debt ratio as one of the variable to represent firm leverage. The result show as the firm leverage is significant to impact financial distress. The study further explain as firm leverage become higher to finance the assets, the firm's level of financial distress risk will increase. The result similar to Pham Vo Ninh et al. (2018).

Waqas and Md-Rus (2018) found that total liabilities to total assets and interest coverage ratio are significant in predicting financial distress. The study shows that leverage ratios are very important in predicting financial distress as to directly relate to how firm managing it liability. Vo et al. (2019) used book value of equity to total debt and total market value of equity to total debt as ratios that represent the leverage ratios in their model. The result obtained quite unique since both ratios shows significant to predict financial distress only on post global financial crisis. This indicate that the predictability of leverage ratios are vary in different period of economy. 
Volume 3 Issue 7 (June 2021) PP. 01-19

DOI 10.35631/AIJBAF.37001

Ogachi et al. (2020) used debt equity ratio and debt ratio to represent leverage ratios in their prediction model. The result obtained show both ratios were significant in predicting financial distress. This result similar to Fitri and Syamwil (2020). Fitri and Syamwil (2020) explained that firms with high level of debt increase the probability of default which could lead to financial distress. Rafatnia et al. (2020) used current liabilities to total equity to represent leverage ratio. The result shows that this ratio found to be positively significant to predict financial distress which indicate the probability of firms to be in financial distress situation will increase as firm leverage level increase.

\section{Methodology}

\section{Data}

This study focused on firms listed in the Malaysian stock market over the period of 2000-2018. However, firms in financial and properties sectors were excluded from the sample of the study due to the highly volatile ratios that are heavily influenced by the economic condition and the slight difference in the interpretation of ratios (Md-Rus \& Abdullah, 2005). Two sets of data were created, namely, the main sample and the holdout sample. For logit model, 1078 firms were used to develop the prediction model and 273 firms were used as the holdout sample. For hazard model, 12353 firm-year observations were used to develop the prediction model and 3963 firm-tear observations were used as the holdout sample. This study focused on firms listed in the Malaysian market because listed firms are significant players within this market. The selected firms were later classified into two categories, namely, (1) financially distressed firms and (2) non-financially distressed firms.

This study defined a financially distressed firm as a firm that has been classified by Bursa Malaysia as a financially distressed firm under Practice Note 4 (PN4), PN17, or/and the amended PN17, and a firm with a deficit in the adjusted shareholders' equity on a consolidated basis. Firms that did not fall under these criteria were classified as non-financially distressed firms. Unlike Ong, Yap, and Kong (2011) and Abdullah et al. (2008), this study did not match the number of non-financially distressed firms against the number of financially distressed firms in order to avoid sample bias, as highlighted by Sori, Hamid, Nassir, and Mohamad (2001).

Annual financial reports for both groups of firms were obtained from the Bloomberg terminal. Financial information was used to calculate the financial ratios for each firm for each year. These ratios - liquidity, profitability, leverage, and efficiency ratios - formed the independent variables or predictors in developing the financial distress prediction models.

\section{Financial Distress Prediction Models}

This study used two statistical approaches to predict financial distress, namely, (1) the logistic regression model or known as the logit model and (2) the hazard model.

According to Shumway (2001), the logistic model is a statistical technique that is appropriate when the independent variables are metric variables and the dependent variable is a non-metric (categorical nominal) variable. This is because the logistic analysis aims to identify the best fitting model to explain the relationship between the predictors or explanatory variables and the dependent variable using the most parsimonious yet reasonable model based on statistics. 
Volume 3 Issue 7 (June 2021) PP. 01-19

DOI 10.35631/AIJBAF.37001

This study adopted the logit prediction model by Ohlson (1980) and Abdullah and Halim (2005), based on the following equation:

$$
\mathrm{Z}_{i}=\beta^{\prime} x_{i}+u_{i}
$$

where:

$\mathrm{Z}_{i}=$ non-distressed if $\mathrm{Z}_{i}>0, \mathrm{Z}_{i}$ ranges from $-\infty$ to $+\infty$

$\mathrm{Z}_{i}=$ distressed, otherwise

$x_{i}=$ Firms' financial ratios

$u_{i}=$ error term

Non-distressed firms' probability and likelihood function could simply be defined as follows:

$$
P_{i}=\frac{1}{1+e^{-z_{i}}}
$$

where:

$$
\mathrm{Z}_{i}=\beta^{\prime} x_{i}+u_{i}
$$

In detail, it is written as follows:

$$
P_{i}=E\left(Y=2 \mid x_{i}\right)=\frac{1}{1+e^{-\left(\beta^{\prime} x i+u i\right)}}
$$

Equation (3) represents the cumulative logistic distribution function. Equation (1) is used to estimate the weight of each financial ratio of the selected firms. Based on equation (3), if $P_{i}$ represents the probability of non-distress, then $\left(1-P_{i}\right)$ represents the probability of distress. Thus,

$$
1-P_{i}=E\left(Y=2 \mid x_{i}\right)=\frac{1}{1+e^{\left(\beta^{\prime} x i+u i\right)}}
$$

The optimal weight, $\beta$, could be estimated where the likelihood value is maximised. In order to obtain the probability of distress, $\beta$ is substituted into the cumulative probability function (equation 4). Based on the calculated probability from the logit model, firms with a probability of less than 0.5 were classified as non-distressed firms. In contrast, firms with a probability of more than 0.5 were classified as distressed firms.

Further, the hazard model was used to assess how well each predictor variable explains the actual probability of distress in the sample used. It is expressed by the following equation:

$$
\Phi_{i, t}=\frac{e^{a(t)+\beta X_{i, t}}}{1+e^{a(t)+\beta X_{i, t}}}
$$

where $X$ represents a vector of the predictor variables used to predict distress, $a(t)$ is a timevarying covariate, $\beta$ is the coefficient of the predictor variables, and $\Phi_{i, t}$ is the hazard model. The main reason that this study used this model is that it is suitable for analysis that includes binary, time-series, and cross-sectional observations like financial distress data. Although the estimation of the hazard model is similar to the logit model in terms of the same likelihood 
Volume 3 Issue 7 (June 2021) PP. 01-19

DOI 10.35631/AIJBAF.37001

function and the same asymptotic variance-covariance matrix, the hazard model uses timevarying covariates and firm-year observations. These help to eliminate sample selection bias; thus, the generated results will be more efficient coefficient estimates as all data are used (Abdullah et al., 2008; Md-Rus, 2011).

In this analysis (the hazard model), the firm that failed in year $t$ is coded as 1 and 0 otherwise. If a firm failed in year 7, the firm is coded as 1 only for year 7 while for the previous six years, it is coded as 0 , indicating that the firm was in good condition in those years. However, an adjustment was made to the logit model's statistical test because the hazard model used firmyear data. The test statistics obtained from the estimation were divided by the average number of firm-year per firm. This is because the test statistics obtained from the logit model were based on the number of firms in the data.

The independent variables of both models consisted of the financial ratios, namely, liquidity, activity, profitability, and leverage ratios. The liquidity ratios were represented by two ratios, which are current ratio (CR) and sales to working capital (SWC). Days sales in receivable (DSC) represented the activity ratio. This study used earnings before interest and tax to sales (EBITS) and net profit margin (NPM) to represent profitability in predicting financial distress. Meanwhile, debt ratio (DR), long-term debt to total debt ratio (LDTD), shareholders' funds to total debt (SFTD), and interest coverage ratio (ICR) were used to represent the leverage ratios. Lastly, this study compared both models in terms of accuracy and consistency in predicting financial distress based on the main sample and the holdout sample.

\section{Results and Discussion}

Table 1 shows the descriptive analysis for all the financial ratios used in developing the financial distress predicting models. As indicated by the results of the analysis, the distressed firms obtained lower mean values for the liquidity ratios, represented by CR and SWC, as compared to the non-financially distressed firms. However, the standard deviations of CR and SWC for the financially distressed firms were lower compared to the non-financial distressed firms, indicating that both ratios were more volatile for the non-financially distressed firms than for the financially distressed firms. As for DSC, the financially distressed firms were found to be better in managing their assets to generate sales compared to the non-financially distressed firms, which required more time to manage their accounts receivable. The results in Table 1 also show that the financially distressed firms achieved lower EBITS and NPM compared to the non-financially distressed firms, indicating that the distressed firms faced problems in generating positive operating profits and net incomes from their sales.

Besides, Table 1 shows that the financially distressed firms recorded higher DR compared to the financially distressed firms, indicating the financially distressed firms' higher dependence on debt to finance their assets compared to the non-financially distressed firms. The table also shows that for the proportion of LDTD, the financially distressed firms recorded a lower value compared to the non-financially distressed firms, indicating that most of the debts incurred by the financially distressed firms were short-term debts. Next, the value of SFTD shows that the financially distressed firms depended too much on debt not only to finance their assets but also to cover the negative shareholders' capital of the firms. Lastly, the ICR values indicate that on average, the financially distressed firms had a negative ability to meet their financing costs and interest expenses. In contrast, the non-financially distressed firms had a high ability to meet their financing costs. In terms of the mean difference's significance level for each variable, the Copyright (C) GLOBAL ACADEMIC EXCELLENCE (M) SDN BHD - All rights reserved 
Volume 3 Issue 7 (June 2021) PP. 01-19

DOI 10.35631/AIJBAF.37001

results show that only SWC and DSC were found to be insignificant while other variables were significant. Based on these results, it can be concluded that on average, the financially distressed firms showed poor financial performance compared to the non-financially distressed firms.

Table 1: Mean Difference Analysis

\begin{tabular}{|c|c|c|c|c|c|c|}
\hline & \multicolumn{2}{|c|}{ Healthy firms } & \multicolumn{2}{|c|}{ Distressed firms } & \multirow[b]{2}{*}{ Mean diff } & \multirow[b]{2}{*}{$T$-test } \\
\hline & Mean & Std dev & Mean & Std dev & & \\
\hline $\mathrm{CR}$ & 3.574 & 14.147 & 0.319 & 0.328 & 3.254 & $2.702 * * *$ \\
\hline SWC & 2.991 & 91.651 & -4.099 & 32.146 & 7.091 & 0.888 \\
\hline DSC & 119.630 & 1294.312 & 114.766 & 170.759 & 4.865 & 0.042 \\
\hline EBITS & 0.002 & 2.590 & -2.871 & 5.764 & 2.873 & $12.451 * * *$ \\
\hline NPM & 0.043 & 3.392 & -15.932 & 132.123 & 15.975 & $13.668 * * *$ \\
\hline DR & 0.392 & 0.209 & 578.838 & 6669.047 & -578.446 & $10.162 * * *$ \\
\hline LDTD & 0.214 & 0.202 & 0.084 & 0.154 & 0.130 & $6.685 * * *$ \\
\hline SFTD & 3.879 & 15.964 & -0.335 & 0.280 & 4.213 & $3.100 * * *$ \\
\hline ICR & 446.547 & 8599.457 & -891.743 & 9867.264 & 1338.29 & $1.782 * *$ \\
\hline
\end{tabular}

NOTE: CR represents the current ratio, SWC represents sales to working capital, DSC represents days sales in the accounts receivable, EBITS represents earnings before interest and tax to sales, NPM represents net profit margin, DR represents the debt ratio, LDTD represents long-term debt to total debt, SFTD represents shareholders' funds to total debt, and ICR represents the interest coverage ratio. The star symbol $(*)$ on the $p$ value represents statistical significance at a certain level; *** statistically significant at the $1 \%$ level, ** statistically significant at the $5 \%$ level, and * statistically significant at the $10 \%$ level.

Tables 2 and 3 show the correlation analyses for all the variables used in the study under the hazard model and logit model, respectively. A correlation analysis examines the strength of correlation among variables. Table 2 shows that the correlations among most of the independent variables were less than 0.8 , showing moderate or weak correlations among them. These results indicate that there was no multicollinearity issue among the selected independent variables.

Table 2: Correlation Matrix (Hazard Model)

\begin{tabular}{cccccccccc}
\hline & CR & SWC & DSC & EBITS & NPM & DR & LDTD & SFTD & ICR \\
\hline CR & 1 & & & & & & & & \\
SWC & -0.0043 & 1 & & & & & & & \\
DSC & 0.0125 & -0.0008 & 1 & & & & & & \\
EBITS & 0.013 & 0.0031 & -0.009 & 1 & & & & & \\
NPM & 0.0113 & 0.0005 & -0.0062 & 0.105 & 1 & & & & \\
DR & -0.1127 & -0.0284 & -0.0012 & -0.1535 & -0.0182 & 1 & & & \\
LDTD & 0.041 & 0.0005 & -0.0048 & 0.0526 & -0.0091 & 0.0199 & 1 & & \\
SFTD & 0.7673 & -0.0062 & 0.0114 & -0.0004 & 0.0096 & -0.1202 & -0.08 & 1 & \\
ICR & 0.0302 & -0.0007 & -0.0014 & 0.0193 & 0.0016 & -0.0122 & -0.0127 & 0.0174 & 1 \\
\hline
\end{tabular}

NOTE: CR represents the current ratio, SWC represents sales to working capital, DSC represents days sales in the accounts receivable, EBITS represents earnings before interest and tax to sales, NPM represents net profit margin, DR represents the debt ratio, LDTD represents long-term debt to total debt, SFTD represents shareholders' funds to total debt, and ICR represents the interest coverage ratio. 
Volume 3 Issue 7 (June 2021) PP. 01-19

DOI 10.35631/AIJBAF.37001

Table 3 provides the correlation analysis results for the logit model's data. The results show that the correlations among most of the variables were lower than 0.8 , indicating the existence of moderate or weak correlations among the variables. These results show that the variables did not suffer from the multicollinearity problem.

Table 3: Correlation Matrix (Logit Model)

\begin{tabular}{cccccccccc}
\hline & CR & SWC & DSC & EBITS & NPM & DR & LDTD & SFTD & ICR \\
\hline CR & 1 & & & & & & & & \\
SWC & -0.0228 & 1 & & & & & & & \\
DSC & 0.0331 & -0.0068 & 1 & & & & & & \\
EBITS & -0.2047 & 0.0219 & -0.1846 & 1 & & & & & \\
NPM & 0.043 & 0.0027 & 0.0065 & 0.0159 & 1 & & & & \\
DR & 0.0095 & -0.0024 & -0.0003 & -0.0221 & -0.0024 & 1 & & & \\
LDTD & 0.049 & -0.0003 & 0.011 & 0.0471 & -0.0732 & 0.0417 & 1 & & \\
SFTD & 0.5521 & -0.0216 & 0.0104 & -0.1549 & 0.2598 & 0.001 & 0.0199 & 1 & \\
ICR & 0.0282 & -0.0033 & -0.0088 & 0.0406 & 0.0042 & -0.0033 & -0.0482 & 0.0078 & 1 \\
\hline
\end{tabular}

NOTE: CR represents the current ratio, SWC represents sales to working capital, DSC represents days sales in the accounts receivable, EBITS represents earnings before interest and tax to sales, NPM represents net profit margin, DR represents the debt ratio, LDTD represents long-term debt to total debt, SFTD represents shareholders' funds to total debt, and ICR represents the interest coverage ratio.

This study then proceeded with the regression analysis based on the hazard and logit models. The results in Table 4 show that CR and SWC were negatively significant in predicting financial distress based on hazard model, which is similar to the findings of Altman et al. (1977), Chiaramonte and Casu (2016), Parker et al. (2002), Rashid and Abbas (2011) and Ogachi et al. (2020). These results indicate that as firms' liquidity increases, the ability to meet their short-term obligations with current assets will increase and hence, reduce the firms' probability of getting financially distressed. However, both CR and SWC were found to be insignificant in predicting financial distress in the logit model, thus contradicting the hazard model's results. This situation could be due to the inability of the logit model to capture the effect of CR and SWC in predicting financial distress.

Table 4: Regression Results

\begin{tabular}{cccc|ccc}
\hline & \multicolumn{3}{c|}{$\begin{array}{c}\text { Hazard } \\
\text { Model }\end{array}$} & \multicolumn{3}{c}{$\begin{array}{c}\text { Logit } \\
\text { Model }\end{array}$} \\
\hline & Coefficient & $\chi^{2}$ & P-value & Coefficient & $\chi^{2}$ & P-value \\
\hline CONST & -53.341 & 24.552 & $0.0000^{* * *}$ & -5.987 & 85.627 & $0.0000^{* * *}$ \\
CR & -3.449 & 18.356 & $0.0000^{* * *}$ & -0.114 & 0.832 & 0.3618 \\
SWC & -0.004 & 16.000 & $0.0001 * * *$ & 0.001 & 0.111 & 0.7389 \\
DSC & 0.001 & 100.000 & $0.0000^{* * *}$ & -0.003 & 9.000 & $0.0027 * * *$ \\
EBITS & 0.328 & 12.439 & $0.0004 * * *$ & -1.605 & 19.230 & $0.0000^{* * *}$ \\
NPM & -0.227 & 5.8317 & $0.0157 * *$ & -0.815 & 13.238 & $0.0003 * * *$ \\
DR & 54.102 & 23.317 & $0.0000^{* * *}$ & 7.751 & 77.0538 & $0.0000^{* * *}$ \\
LDTD & -0.759 & 0.3175 & 0.5731 & -2.061 & 4.405 & $0.0358^{* *}$ \\
SFTD & 1.010 & 25.2494 & $0.0000^{* * *}$ & 0.053 & 0.292 & 0.5886 \\
ICR & -0.001 & 25.000 & $0.0000^{* * *}$ & 0.00009 & 0.090 & 0.7642 \\
\hline
\end{tabular}

NOTE: The $\chi^{2}$ test or Wald Chi-square represent $\chi^{2}$ distribution with one degree of freedom test that use to test predictive significance of each individual predictor variable. As for hazard model, this study adjusted $\chi^{2}$ value by 
Volume 3 Issue 7 (June 2021) PP. 01-19

DOI 10.35631/AIJBAF.37001

dividing the $\chi^{2}$ value with average number of firm-year per year (11.3) since many years observations for same firmCR represents the current ratio, SWC represents sales to working capital, DSC represents days sales in the accounts receivable, EBITS represents earnings before interest and tax to sales, NPM represents net profit margin, DR represents the debt ratio, LDTD represents long-term debt to total debt, SFTD represents shareholders' funds to total debt, and ICR represents the interest coverage ratio. The star symbol $(*)$ on the $p$-value represents statistical significance at a certain level; *** statistically significant at the $1 \%$ level, ** statistically significant at the $5 \%$ level, and ${ }^{*}$ statistically significant at the $10 \%$ level.

As shown in Table 4, both models used DSC to represent the activity ratio. The results for the hazard model show that this variable was positively significant in predicting financial distress, which is in line with Ong et al. (2011). Thus, the faster firms collect payments from their credit sale, the lower will be the probability of getting into financial distress since more revenues are collected within a shorter period, which can be used to cover the debts. However, the results of the logit model show that DSC was negatively significant in predicting financial distress, which contradicts the findings of Parker et al. (2012) and Ong et al. (2011). Despite the mixed results generated by the models, these findings show that the activity ratio is one of the important ratios for predicting financial distress.

Table 4 also shows the results for the profitability ratios. The hazard model obtained mixed results for EBITS and NPM. EBITS was found to be positively significant, indicating that as firms' EBITS increases, the probability of getting into financial distress will also increase. This is because firms with high EBITS have the potential to obtain more debts or loans, which would increase the probability of getting financially distressed if the firms failed to manage their debts.

Meanwhile, the hazard model showed that NPM was negatively significant in predicting financial distress, which is similar to the results of the logit model which showed that both profitability ratios were negatively significant in predicting financial distress. These significant results are similar to Juniarti (2013), Polemis and Gounopoulos (2012), Thai et al. (2014), and Bakhri et al. (2018). These results indicate that a high ability to generate profits will help firms to reduce their financial distress risk. Despite the mixed results obtained from both models, the results still show the importance of profitability ratios in predicting financial distress.

Besides, Table 4 shows that the DR values were positively significant for both models, which are in line with the theoretical argument that a firm with a high debt level has a high probability of facing financial distress. These results are similar to Alifiah and Tahir (2018), Lee and Yeh (2004), Sori et al. (2001), and Tinoco and Wilson (2013), which found that over-financing of assets using debts could lead to financial distress.

For other variables, this study obtained mixed results under both models. Table 4 shows that ICR was negatively significant in predicting financial distress in the hazard model, which is similar to the results of Fich and Slezak (2008) and Youn and Gu (2010). Firms need to maintain and increase this ratio to avoid defaulting on their interest payments, which could lead to severe financial distress (Youn \& Gu, 2010). However, the results of the logit model in Table 4 show that ICR was positively insignificant in predicting financial distress, which contradicts the hazard model's results and the previous studies of Fich and Slezak (2008) and Youn and $\mathrm{Gu}(2010)$. 


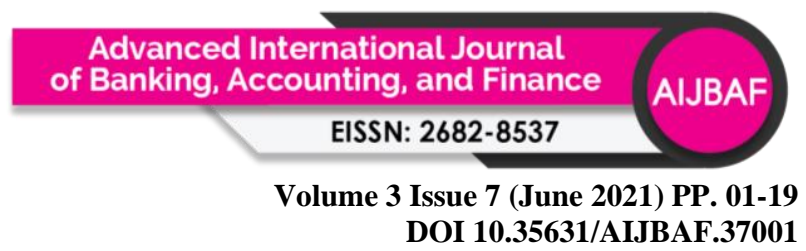

Another leverage ratio that was positively significant in predicting financial distress in the hazard model is SFTD, which contradicts the results of Abdullah and Halim (2005), Gilbert, Menon, and Schwartz (1990), and Ugurlu and Aksoy (2006). This study's result can be explained as a firm that depends too much on equity or shareholders' funds might have to pay a high tax, which will reduce the firm's profitability and might lead to financial distress. However, in the logit model the result showed that SFTD was insignificant. The contradicted results between the hazard and the logit model showed that the average yearly data used in the logit model did not capture the effect of SFTD in predicting financial distress.

Lastly, LTTD was found to be insignificant in predicting financial distress in the hazard model which is similar to Vuran (2009) but contradicts Ugurlu and Aksoy (2006). The possible reason for this phenomenon is the proportion of long-term debt does not provide vital information for the prediction of financial distress since shareholders' capital fully funds some firms while other firms might have minimal long-term debts. However, LTTD was found to be negative and significant in predicting financial distress based on the logit model. This result is similar to Ugurlu and Aksoy (2006) who stressed that when long-term to total debt ratio is too low, it might suggest that a firm is relying more on short-term financing compared to long-term financing. This situation will create liquidity problem which will increase the probability of financial distress problem.

This study then proceeded to examine the accuracy rate of each model in order to check the models' reliability. Based on Table 5, the hazard model had an overall accuracy rate of 99.92 per cent for the whole sample. The model was able to predict financially distressed firms correctly 94.28 per cent of the time and predict non-financially distressed firms correctly 99.97 per cent of the time. The accuracy rate is considered high and is in line with Md-Rus (2011), Shumway (2001), and Wang and Wu (2017). The classification accuracy of the logit model is also presented in Table 5, which shows that the logit model was able to accurately predict nonfinancially distressed firms at the 99.06 per cent accuracy level. However, the ability of the logit model to accurately predict financially distressed firms is considered moderate because it had only 65.51 per cent accuracy level. Overall, the model had an accuracy rate of 94.60 per cent in predicting all cases within the sample used. Thus, these results show that the hazard model had a better accuracy level compared to the logit model in all aspects, which is similar to the results of Abdullah et al. (2008).

In order to check the reliability of the results for the main sample, this study performed an analysis using a holdout sample. For the logit holdout sample, the study used the data for 273 randomly picked firm from 1990 to 2018 and for the hazard model, holdout sample used 3963 observations. The classification accuracy for the holdout model is presented in Table 6, which shows that the hazard model was able to generate consistent results for the holdout sample. This is because the hazard model correctly predicted 92.31 per cent of the financially distressed firms and 99.92 per cent of the non-financially distressed firms, which are similar to accuracy rates obtained by the original model. Next, Table 6 shows the accuracy of the logit model for the holdout sample, where the logit model was able to accurately predict 76.92 per cent of the financially distressed firms, which is higher than the accuracy rate achieved under the original logit model. The model also accurately predicted non-financially distressed firms 92.69 per cent of the time. These results show that the accuracy rates of the logit model were not consistent between the holdout sample and the main sample. 
Volume 3 Issue 7 (June 2021) PP. 01-19

DOI 10.35631/AIJBAF.37001

Table 5. Accuracy Analysis for the Main Sample

\begin{tabular}{|c|c|c|c|c|c|c|c|c|c|}
\hline & \multicolumn{3}{|c|}{ Hazard Model } & \multicolumn{6}{|c|}{ Logit Model } \\
\hline & \multicolumn{3}{|c|}{ Predicted } & \multicolumn{6}{|c|}{ Predicted } \\
\hline & & $\mathbf{0}$ & 1 & $\begin{array}{l}\text { Percentage } \\
\text { Correct }(\%)\end{array}$ & & & 0 & 1 & $\begin{array}{l}\text { Percentage } \\
\text { correct }(\%)\end{array}$ \\
\hline Actual & 0 & 12245 & 3 & 99.97 & Actual & 0 & 845 & 8 & 99.06 \\
\hline & 1 & 6 & 99 & 94.28 & & 1 & 45 & 84 & 65.51 \\
\hline $\begin{array}{l}\text { Overall } \\
\text { Accuracy }\end{array}$ & & & & 99.92 & $\begin{array}{l}\text { Overall } \\
\text { Accuracy }\end{array}$ & & & & 94.60 \\
\hline
\end{tabular}

The logit model obtained a higher overall accuracy rate for the main sample compared to the holdout sample. The inconsistent results generated by the logit model for the main sample and the holdout sample provide proof of the inconsistency problems faced by the logit model in predicting financial distress, as highlighted by Shumway (2001). This holdout sample analysis demonstrates that the hazard model is superior to the logit model in terms of generating consistent results.

Table 6. Accuracy Analysis for the Holdout Sample

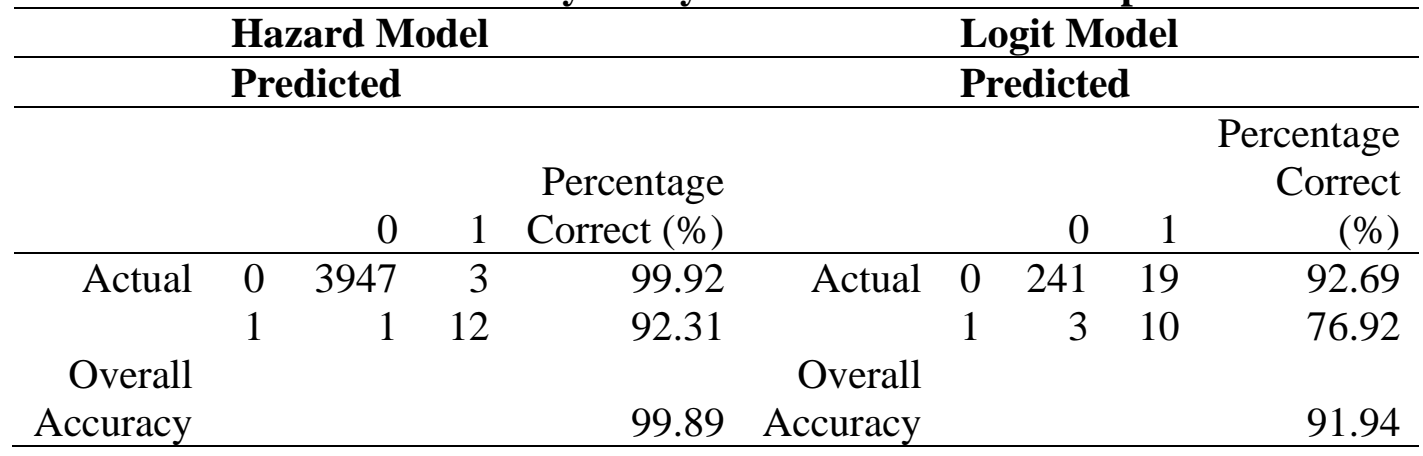

\section{Conclusion and Recommendations}

This study focused on developing financial distress prediction models for the Malaysian market and comparing the logit model against the hazard model in predicting financial distress using financial ratios. The results demonstrated that all the selected ratios except long-term debt to total debt were significant in the hazard model. Meanwhile, days sales in receivable, earnings before interest and tax to sale, net profit margin, debt ratio, and long-term debt to total debt ratio were significant in predicting financial distress based on the logit model. These two different sets of results are due to the nature of the data used for both models, where the hazard model used panel data based on annual financial ratios for each firm in each year while the logit model used average annual financial ratios for each firm. In terms of accuracy, this study found the hazard model to be more accurate compared to the logit model in predicting financial distress and non-financial distress cases. The hazard model was also found to generate similar accuracy rates for the holdout sample, indicating that this model is consistent in predicting financial distress.

Meanwhile, the logit model generated inconsistent results in predicting financial distress for the holdout sample. These findings provide evidence of the problems faced by the logit model as highlighted by Shumway (2001). Based on all these results, the hazard model has been 
Volume 3 Issue 7 (June 2021) PP. 01-19

DOI 10.35631/AIJBAF.37001

shown to exhibit superior performance compared to the logit model in predicting financial distress in the Malaysian market.

Lastly, this study suggests the inclusion of more predictors such as cash flow ratios, market ratios, corporate governance variables, and macroeconomic variables into the model in order to obtain a comprehensive model that considers all aspects in predicting financial distress. Future research should try to compare as many models as possible in order to generate the best model specific for the Malaysian market that could accurately predict financial distress and could be applied for all market players.

\section{References}

Abdul Manab, N., Yen, N., \& Md-Rus, R. (2015). The Determinants of Credit Risk in Malaysia. Procedia - Social and Behavioral Sciences, 172, 301-308. https://doi.org/10.1016/j.sbspro.2015.01.368

Abdullah, N. A., \& Ahmad, A. H. H. (2005). Detecting Financial Distress. International Journal of Management, 12(1), 77-95.

Abdullah, N. A., Halim, A., Ahmad, H., \& Md-rus, R. (2008). Predicting corporate failure of Malaysia's listed companies: Comparing multiple discriminant analysis, logistic regression and the hazard model. International Research Journal of Finance and Economics, 15, 201-217.

Abdullah, S. N. (2006). Board structure and ownership in Malaysia: the case of distressed listed companies. Corporate Governance, 6(5), 582-594. https://doi.org/10.1108/14720700610706072

Alifiah, M., \& Tahir, M. (2018). Predicting financial distress companies in the manufacturing and non-manufacturing sectors in Malaysia using macroeconomic variables. Management Science Letters, 8(6), 593-604.

Altman, E. I. (1968). Financial ratios, discriminant analysis and the prediction of corporate bankruptcy. The Journal of Finance, XXIII(4), 589-609.

Altman, E. I., Haldeman, R. G., \& Narayanan, P. (1977). ZETATM analysis A new model to identify bankruptcy risk of corporations. Journal of Banking \& Finance, 1(1), 29-54. https://doi.org/10.1016/0378-4266(77)90017-6

Bakhri, S., Listyaningsih, E., \& Nurbaiti. (2018). Pengaruh Likuiditas Dan Profitabilitas Terhadap Financial Distress Pada Perusahaan Transportasi. Jurnal Riset Akuntansi Dan Manajemen, 7(1), 40-47.

Beaver, W. H., McNichols, M. F., \& Rhie, J. W. (2005). Have financial statements become less informative? Evidence from the ability of financial ratios to predict bankruptcy. Review of Accounting Studies, 10(1), 93-122.

Blum, M. (1974). Failing Company Discriminant Analysis. Journal of Accounting Research, 12(1), 1-25.

Chen, Y., Zhang, L., \& Zhang, L. (2013). Financial Distress Prediction for Chinese Listed Manufacturing Companies. Procedia Computer Science, 17, 678-686. https://doi.org/10.1016/j.procs.2013.05.088

Chiaramonte, L., \& Casu, B. (2016). Capital and Liquidity Ratios and Financial Distress. Evidence from the European Banking Industry. The British Accounting Review.

Daily, C. M., \& Dalton, D. R. (1994). Bankruptcy and Corporate Governance: the Impact of Board Composition and Structure. Academy of Management Journal, 37(6), 16031617. https://doi.org/10.2307/256801 


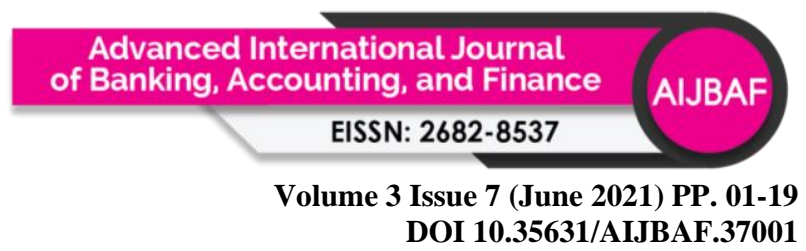

Darmawan, A., \& Supriyanto, J. (2018). The Effect of Financial Ratio on Financial Distress in Predicting Bankruptcy. Journal of Applied Managerial Accounting, 2(1), 110-120.

Elloumi, F., \& Gueyié, J.-P. (2001). Financial distress and corporate governance: an empirical analysis. Corporate $\quad$ Governance, 1(1), 15-23. https://doi.org/10.1108/14720700110389548

Fich, E. M., \& Slezak, S. L. (2008). Can corporate governance save distressed firms from bankruptcy? An empirical analysis. Review of Quantitative Finance and Accounting, 30(2), 225-251. https://doi.org/10.1007/s11156-007-0048-5

Fitri, R. A., \& Syamwil, S. (2020). Pengaruh Likuiditas, Aktivitas, Profitabilitas dan Leverage Terhadap Financial Distress (Studi Kasus pada Perusahaan Manufaktur yang Terdaftar di Bursa Efek Indonesia Periode 2014-2018). Jurnal Ecogen, 3(1), 134. https://doi.org/10.24036/jmpe.v3i1.8532

Foster, B. P., \& Zurada, J. (2013). Loan defaults and hazard models for bankruptcy prediction. Managerial Auditing Journal, 28(6), 516-541. https://doi.org/10.1108/02686901311329900

Ganesalingam, S., \& Kumar, K. (2001). Detection of Financial Distress via Multivariate Statistical Analysis. Managerial Finance, 27(4), 45-55.

Gilbert, L. R., Menon, K., \& Schwartz, K. B. (1990). Predicting bankruptcy for firms in financial distress. Journal of Business Finance \& Accounting, 17(1), 161-171.

Hillegeist, S. A., Keating, E. K., Cram, D. P., \& Lundstedt, K. G. (2004). Assessing the Probability of Bankruptcy. Review of Accounting Studies, 9(1), 5-34.

Jaafar, M. N., Muhamat, A. A., Alwi, S. F. S., Karim, N. A., \& Rahman, S. binti A. (2018). Determinants of Financial Distress among the Companies Practise Note 17 Listed in Bursa Malaysia. International Journal of Academic Research in Business and Social Sciences, 8(11), 800-811. https://doi.org/10.6007/ijarbss/v8-i11/4956

Juniarti, J. (2013). Good Corporate Governance and Predicting Financial Distress Using Logistic and Probit Regression Model. Jurnal Akuntansi Dan Keuangan, 15(1), 43-50.

Lee, T., \& Yeh, Y. (2004). Corporate Governance and Financial Distress : evidence from Taiwan. Corporate Governance, 12(3), 378-388.

Lo, A. W. (1986). Logit versus discriminant analysis: A specification test and application to corporate bankruptcies. Journal of Econometrics, 31(2), 151-178.

Md-Rus, R. (2011). An Empirical Investigation on the Relationship between Risk of Bankruptcy and Stock Return. International Journal of Management Studies, 18(1), 117-134.

Md-Rus, R., \& Abdullah, N. A. H. (2005). empirical investigation of failing companies in an emerging capital market. In In 16th Asian Finance Association Conference, Malaysia.

Md-Zeni, S., \& Ameer, R. (2010). Turnaround prediction of distressed companies: evidence from Malaysia. Journal of Financial Reporting and Accounting, 8(2), 143-159.

Ming, X., \& Akhtar, H. (2014). Impact of Corporate Governance on Financial Distress: An Evidence from Shanghai Stock Market An Analysis Based on a Panel Data and Logit Model. Interdisciplinary Journal of Contemporary Research In Business, 6(6), 1-11.

Nam, C. W., Kim, T. S., Park, N. J., \& Lee, H. K. (2008). Bankruptcy prediction using a discrete-time duration model incorporating temporal and macroeconomic dependencies. Journal of Forecasting, 27(6), 493-506.

Noor, Z., Iskandar, T. and, \& Omar, N. (2012). Malaysian Companies Distress Prediction: DEA and Multinomial Logit Model. PROSIDING PERKEM VII, 2, 1536-1551. Retrieved from http://scholar.google.com/scholar?hl=en\&btnG=Search\&q=intitle:Malaysian+Compa 
Volume 3 Issue 7 (June 2021) PP. 01-19 DOI 10.35631/AIJBAF.37001

nies+Distress+Prediction+:+DEA+and+Multinomial+Logit+Model\#0\%5Cnhttp://sch olar.google.com/scholar?hl=en\&btnG=Search\&q=intitle:Malaysian+Companies+Dist ress+Prediction:+DEA+and+Multi

Nyamboga, T. O., Omwario, B. N., Muriuki, A. M., \& Gongera, G. (2014). Determinants of Corporate Financial Distress: Case of Non- Financial Firms Listed in the Nairobi Securities Exchange. Research Journal of Finance and Accounting, 5(12), 193-207.

Ogachi, D., Ndege, R., Gaturu, P., \& Zoltan, Z. (2020). Corporate Bankruptcy Prediction Model, a Special Focus on Listed Companies in Kenya. Journal of Risk and Financial Management, 13(3), 47. https://doi.org/10.3390/jrfm13030047

Ohlson, J. A. (1980). Financial Ratios and the Probabilistic Prediction of Bankruptcy. Journal of Accounting Research, 18(1), 109-131.

Ong, S.-W., Yap, V. C., \& Khong, R. W. L. (2011). Corporate failure prediction: a study of public listed companies in Malaysia. Managerial Finance, 37(6), 553-564. https://doi.org/10.1108/03074351111134745

Parker, S., Peters, G. F., \& Turetsky, H. F. (2002). Corporate governance and corporate failure: a survival analysis. Corporate Governance: The International Journal of Business in Society, 2(2), 4-12. https://doi.org/10.1108/14720700210430298

Pham Vo Ninh, B., Do Thanh, T., \& Vo Hong, D. (2018). Financial distress and bankruptcy prediction: An appropriate model for listed firms in Vietnam. Economic Systems, 42(4), 616-624. https://doi.org/10.1016/j.ecosys.2018.05.002

Pindado, J., Rodrigues, L., \& de la Torre, C. (2008). Estimating financial distress likelihood. Journal of Business Research, 61(9), 995-1003. https://doi.org/10.1016/j.jbusres.2007.10.006

Polemis, D., \& Gounopoulos, D. (2012). Prediction of Distress and Identification of Potential M\&As Targets in UK. Managerial Finance, 38(11), 1085-1104. https://doi.org/10.1108/03074351211266801

Rafatnia, A. A., Ramakrishnan, S., Abdullah, D. F. B., Nodeh, F. M., \& Farajnezhad, M. (2020). Financial distress prediction across firms. Journal of Environmental Treatment Techniques, 8(2), 646-651.

Rashid, A., \& Abbas, Q. (2011). Predicting Bankruptcy in Pakistan. Theoretical \& Applied Economics, 18(9).

Sathye, M., Bartle, J., Vincent, M., \& Boffey, R. (2003). Credit Analysis and Lending Management (illustrate). Wiley.

Shumway, T. (2001). Forecasting Bankruptcy Mode Accurately: A Simple Hazard Model. The Journal of Business, 74(1), 101-124.

Sori, Z. M., Hamid, M. A. A., Nassir, A. M., \& Mohamad, Z. A. (2001). Forecasting corporate failure in Malaysian industrial sector firms. Asian Academy of Management Journal.

Tan, C. N. W., \& Dihardjo, H. (2001). A study of using artificial neural networks to develop an early warning predictor for credit union financial distress with comparison to the probit model A Study on Using Artificial Neural Networks to Develop an Early Warning Predictor for Credit Union Fi. Managerial Finance, 27(4), 56-77.

Thai, S. B., Goh, H. H., Teh, B. H., Wong, J. C., \& Ong, T. S. (2014). A Revisited of Altman Z- Score Model for Companies Listed in Bursa Malaysia. International Journal of Business and Social Science, 5(12), 197-207.

Tinoco, M. H., \& Wilson, N. (2013). Financial distress and bankruptcy prediction among listed companies using accounting, market, and macroeconomic variables. International Review of Financial Analysis, 30, 394-419. 
Volume 3 Issue 7 (June 2021) PP. 01-19

DOI 10.35631/AIJBAF.37001

Tirapat, S., \& Nittayagasetwat, A. (1999). An investigation of Thai listed firms' financial distress using macro and micro variables. Multinational Finance Journal, 3(2), 103125 . http://search.proquest.com/docview/202825369?accountid=10297\%5Cnhttp://sfx.cran field.ac.uk/cranfield?url_ver=Z39.88-

2004\&rft_val_fmt=info:ofi/fmt:kev:mtx:journal\&genre=article\&sid=ProQ:ProQ\%253 Aabiglobal\&atitle $=$ An+investigation+of + Thai+listed+firms $\% 2527+$ financi

Ugurlu, M., \& Aksoy, H. (2006). Prediction of corporate financial distress in an emerging market: the case of Turkey. Cross Cultural Management: An International Journal, 13(4), 277-295.

Vo, D. H., Pham, B. N. V., Ho, C. M., \& McAleer, M. (2019). Corporate Financial Distress of Industry Level Listings in Vietnam. Journal of Risk and Financial Management, 12(4), 155. https://doi.org/10.3390/jrfm12040155

Vuran, B. (2009). Prediction of business failure: a comparison of discriminant and logistic regression analyses. Istanbul University Journal of the School of Business Administration, 38(1), 47-65.

Wang, L., \& Wu, C. (2017). Business failure prediction based on two-stage selective ensemble with manifold learning algorithm and kernel-based fuzzy self-organizing map. Knowledge-Based Systems, 121, 99-110.

Wang, Z., \& Li, H. (2007). Financial distress prediction of Chinese listed companies: a rough set methodology. Chinese Management Studies, 1(2), 93-110. https://doi.org/10.1108/17506140710758008

Waqas, H., \& Md-Rus, R. (2018). Predicting financial distress: Importance of accounting and firm-specific market variables for Pakistan's listed firms. Cogent Economics and Finance, 6(1), 1-16. https://doi.org/10.1080/23322039.2018.1545739

Wilson, R. L., \& Sharda, R. (1994). Bankruptcy prediction using neural networks, 11, 545557.

Yap, B. C. F., Munuswamy, S., \& Mohamed, Z. (2012). Evaluating Company Failure in Malaysia Using Financial Ratios and Logistic Regression. Asian Journal of Finance \& Accounting, 4(1), 330-344. https://doi.org/10.5296/ajfa.v4i1.1752

Youn, H., \& Gu, Z. (2010). Predicting Korean lodging firm failures: An artificial neural network model along with a logistic regression model. International Journal of Hospitality Management, 29(1), 120-127. https://doi.org/10.1016/j.ijhm.2009.06.007 